\title{
Usefulness of Certain Animal/Plant Genetic Resources in Enhancing Food and Nutritional Security under Changing Climatic Conditions
}

\author{
P. Jayaseela Rao ${ }^{1}$, G. Prabhakara Rao*2, Paresh Chandra Kole ${ }^{3}$ \\ ${ }^{1}$ Indian Meteorological Department, Chennai - 600027, Tamil Nadu, India. Email: jayaseelaraop@ gmail.com \\ ${ }^{2}$ Rubber Research Institute of India, Kottayam - 686009, Kerala, India. Email: raogprao@ gmail.com \\ ${ }^{3}$ Department of GPB\&CP, Institute of Agriculture, Visva-Bharati University, Santiniketan -731235, West \\ Bengal, India. Email: pckole@gmail.com \\ *Corresponding author
}

How to cite this paper: Rao, P.J., Rao, G.P. and Kole, P.C. (2018). Usefulness of Certain Animal/Plant Genetic Resources in Enhancing Food and Nutritional Security under Changing Climatic Conditions. Grassroots Journal of Natural Resources, 1(1): 13-25. Doi:

https://doi.org/10.33002/nr2581.6853.01012

Received: 23 June 2018

Reviewed: 26 June 2018; 03 July 2018

Provisionally Accepted: 07 July 2018

Revised: 23 July 2018

Finally Accepted: 31 July 2018

Published: 13 August 2018

Copyright (C) 2018 by author(s) and

The Grassroots Institute.

This work is licensed under the Creative Commons Attribution International License (CC BY 4.0).

http://creativecommons.org/licenses/by/4.0/

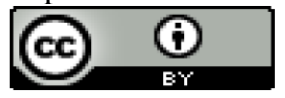

Open Access

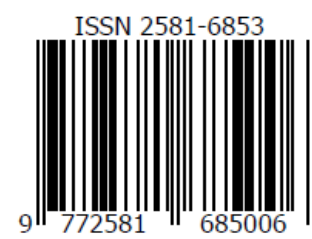

01012

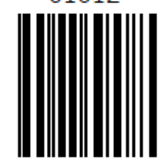

\section{Abstract}

Genetic resources for food and agriculture are the biological basis for world food and nutrition security that can improve the livelihoods. India is one of the mega biodiversity centres, endowed with wide floristic, microbial, animal, marine and freshwater/estuarine diversity. About 40 mammalian species have been domesticated for food but the major contribution in livestock production is from 14 species. It has been estimated that some 1500 breeds of the domestic animal species in the world are now at high risk of extinction. About $30 \%$ of plant species are endemic to India. Global climatic conditions are changing due to indiscriminate anthropogenic activities, leading to loss of biodiversity, ecosystem and natural environment. The genetic erosion of wild and semi-wild relatives of the domesticated crops and animals is alarming due to threats to ecosystems/breeding habitats. Further, they are vulnerable to changing climatic conditions. This germplasm provides raw materials for breeding improvement in terms of higher yields, which in turn enhances food production and nutritional security. Therefore, all the available genetic resources should be conserved for the present and future generations for sustainable development in the years to come.

\section{Keywords}

Biodiversity; Conservation; Climate Change; Environment; Genetic Resources 


\section{Introduction}

Rapid industrialization and deforestation have affected the natural environment, leading to depletion of natural resources and large-scale habitat loss. Deforestation is a pressing environmental problem involving permanent loss of species, soil degradation, impact on global climate change, and long-term resource depletion. Biodiversity is the vast array of all species of plants, animals, insects and the microorganisms inhabiting the earth either in the aquatic or the terrestrial habitats. The human civilization depends directly or indirectly upon this biodiversity for their very basic needs of survival - food, fodder, fuel, timber, medicines, leather and several other raw materials. Biodiversity is conserved at three levels i.e. genetic, species and ecosystem. Global biodiversity is changing at an unprecedented rate, with decline and loss of valuable species (Pimm et al., 1995). Germplasm is the sum total of genes present in a particular species, which are useful in the genetic improvement of a particular plant or animal species for human use. In the case of plants, landraces, traditionally grown primitive cultivars and wild relatives of cultivated plants are the basic materials that not only sustain the present day crop improvement programmes but will also be required to meet the aspiration of future generations. The same is true for domesticated animal genetic resources and their wild relatives. This paper describes various facets of agrobiodiversity, assesses risk of extinctions due to changing climatic conditions, conservation strategies, and the usefulness of vital plant/animal genetic resource for enhancing food production, nutritional security and sustainability.

\section{Global Warming}

The greenhouse effect is a naturally occurring phenomenon that is responsible for heating of Earth's surface and atmosphere. Atmospheric gases such as carbon dioxide, methane, etc. are commonly known as greenhouse gases because they are responsible for the greenhouse effect. Accumulation of greenhouse gases, mainly carbon dioxide, methane and nitrous oxide and chlorofluorocarbons (CFCs), in the atmosphere is contributing to an increase in temperature of earth surface (Moss et al., 2000) leading to global warming. The world recognizes global warming and deforestation as immediate threat caused by drastically changing weather conditions such as changes in the rainfall pattern, fluctuations in temperature, recurrence of drought, floods and heat and cold weather, rise in sea level, local and global ecosystem upsets and changes in the cropping pattern. The consequences of the increase in concentration of the gases that generate the greenhouse effect are that average global temperatures will rise, along with many consequences on human life. The degree to which these changes are projected to occur is dependent upon a reliable greenhouse gas policy model and a range of scenarios for the levels of greenhouse gas emissions. During the past century, the temperature of earth has increased by $0.6^{\circ} \mathrm{C}$, most of it during the last three decades (Houghton et al., 2001). The projected change in global average temperature will likely be from $0.3{ }^{\circ} \mathrm{C}$ to $0.7^{\circ} \mathrm{C}$ for the period 2016-2035 relative to the reference period 1986-2005 (Kirtman et al., 2013).

The projected climatic change in the next century due to the greenhouse effect is likely to have an effect on water supplies and the increase in temperature will induce a new distribution of deserts and wet areas in the world and will alter the range or numbers of pests that affect plants or diseases that threaten animals or human health. Further it triggers deleterious effects on plants, animals, marine and microorganisms. Additionally, of interest are the effects on unmanaged ecosystems, mainly forests (Moss et al., 2000). So, the issue of global warming and the associated climate change at the global scale clearly indicates its effects on bio-resources and its access at local level and they need to be treated cautiously. 


\section{Resource Access and Climate Change Issues}

India constitutes $2.4 \%$ of land and $16 \%$ of populations on the planet earth. India lives in villages with $68.89 \%$ of her population and $98 \%$ her total geographical area (Census of India, 2011) and blessed with an enormous diversity of plants and animals for harnessing food security and good health for all. Being a signatory to the Convention on Biological Diversity (CBD), parliament of India enacted the Biological Diversity Act (BDA), 2002 and the National Biodiversity Authority (NBA) was established in 2003. This law regulates nationally and internationally the access to biological resource, benefit sharing in India and for seeking trade related intellectual property rights as per the provisions laid out in BDA, 2002 and Biological Diversity Rules, 2004. Certain acts provide suitable linkage to provision for patenting of products and processes/technologies based on the use of bio-resources and associated indigenous traditional knowledge (ITK), under section 10(4) of the Patents (Amendment) Act, 2002 (Rana, 2015). The provision for access and benefit sharing was to ensure food and livelihood security based on biological diversity conservation, sustainable use of resources and inclusive development.

In the wake of raising global temperatures and climate change, the existence of rich diversity in the nature is at risk. In 2014, report of the Intergovernmental Panel on Climate Change (IPCC) indicated that agricultural production will reduce by as much as $2 \%$ per decade up to 2050 , while demand could increase by $14 \%$ (IPCC, 2014). Therefore, it is urgently needed to identify some devices or strategies for increasing the food production. Thus, it is essential to assess environmental issues on the judicious use of natural resources to achieve the optimum sustainability. In this context, integration of various systems of agriculture and organic farming also plays a significant role in limited access of small farmers and low input production system. Land degradation has been identified as a source of "poverty traps" in many developing regions (Dasgupta and Maler, 1991; Barbier and Lopez, 1999). The impact of poverty and investment on soil conservation, conservation adoption and differences among households in capacity to bear risk was studied by Shively (2001). The natural resources and environmental issues play critical role in terms of poverty eradication and subsistence of millions of people. Hence, it requires the highest priority within the overall framework of sustainable development goals (SDGs).

\section{Weather and Farming}

Climate change is profoundly impacting the conditions in which agricultural activities are conducted. In general, in every region of the world, plants, animals, and ecosystems are adapted to the prevailing climatic conditions. When these conditions change, even slightly, in a direction that could seem unfavorable, the plants and animals present in that area will be impacted, some will become less productive, or even disappear.

Indian agriculture, in spite of adoption of appropriate agronomic and integrated resources management practices is dependent on variability in weather conditions in general, and on quantum of rainfall during different crop stages in particular. Climatic variability and its diversified nature also affect the agricultural productivity of the region to a great extent. Occurrences of major pests and diseases at different phenophages of the crop are mostly the climatic or weather dependent causing the yield loss of the crop up to 30-35\%. Hence, sustainability of agricultural production is directly or indirectly affected by weather. A successful crop production in the rainfed agriculture depends upon the amount and distribution of rainfall (Prakash and Rao, 1986). Therefore, for forewarning, knowledge of weather and its 
nature are very important to adopt the weather-based management practices of agriculture to boost productivity by adopting the timely preventive measures (Panday et al., 2000; Agarwal et al., 2000). Medium range weather forecast models developed for various regions in India and issued by Department of Science and Technology can be very useful in mitigating the adverse effects of weather. Therefore, research on climate change in relation to adaptation and mitigation for a climate-smart agriculture and farming systems should be strengthened in an interdisciplinary manner.

\section{Integration of Farming Systems and Productivity}

Integration of farming systems such as agro-forestry, agro-plantation, inter-cropping systems along with animal husbandry on farm will definitely play a pivotal role in enhancing farm income and poverty alleviation in the society. A combination of agriculture with fish culture, dairy and poultry farming fetches the small farmers more average net income than other enterprises (Rao, 1992). Integrated farming and organic cultivation can bring a change in the food supply chain, nutritional security and improving health of the people. Organic farming has emerged as a potential alternative for meeting nutritional security, maintaining soil fertility and increasing soil carbon pool. It is a unique production management system which promotes and enhances agroecosystem health (Meder et al., 2002), including biodiversity, biological cycles and soil biological activity, and this is accomplished by using on-farm agronomic, biological and mechanical methods in exclusion of all synthetic off-farm inputs.

Ecosystems play an important role in human societies by providing services that directly or indirectly benefit humans. The productivity of an ecosystem refers to the rate of production i.e. the amount of organic matter, which is accumulated in any unit time. Due to anthropogenic activities and changing climatic conditions, soil fertility eroding continuously, leading to the development of vast unfertile wastelands. The land productivity has changed dramatically with ample literature indicating the loss of crop yields in recent times (Nigam et al., 2000; Patil and Ramteke, 2000). Ecosystems are negatively affected by human activities such as pollution, over exploitation of natural resources, and habitat degradation. The Millennium Ecosystem Assessment in 2005 revealed that about two-thirds of global ecosystem services were in the state of decline and the harmful consequences of this decline could grow significantly worse in the coming decades (MEA, 2005). So, the best way is to avoid degradation, minimize the risks to species and ecosystem processes, and obtain and maintain long-term socio-economic benefits without compromising the ecosystem resilience.

Deforestation is the conversion of forested areas to non-forested purposes. According to an estimate, almost 40 per cent forests have been lost in the tropics, compared to only one per cent in the temperate region. The present situation in India is grim, as the forest cover is shrinking to below 20 per cent. In this context, planting of trees has a positive effect on restoration of these degraded lands and transforming it into the sustainable ecosystem. Global consultation on the use and management of agrobiodiversity for sustainable food security organized by Biodiversity International held in New Delhi, India during February 12-14, 2013 recommended the need for studies on ecosystem diversity and the interactions among component communities, so that it may provide insight to mitigate effects of climate change (Anonymous, 2013a). 


\section{Extent of Biodiversity}

Even though, the exact figures of global biodiversity are not known, available rough estimates are indication of vast diversity on earth. According to expert estimates, 70-80 million species are present on earth. Global biodiversity assessment estimated that total number of animal and plant species to be between 13 and 4 million, respectively (Thrupp, 1998). It further records that so far only 1.75 million species have been described and studied. About 5,000 species are economically useful and 583 species have been cultivated by humankind. Geneticists have described 334 wild relatives of crops and explorers have identified 1,000 wild edible plant species. Ecosystem diversity has not been even reasonably explored as yet. Hence, there seems to be a wide gap of knowledge at global, regional and local levels.

Conservation International (CI) group's first ever global estimate of tree database revealed that around 9,600 tree species are threatened with extinction and identified a total of 60,065 in existence (Beech et al., 2017). Brazil is the country with the most diverse tree population, with 8,715 species. Globally, it is a well known fact that Amazon tropical rainforests in Brazil is one of the main mega biodiversity centers with rich species diversity; it has the huge number of economic plant species, and these species are used by people in our daily life such as soybean, maize, rice, beans, cotton, wheat, tea, coffee, cassava, cocoa, rubber, etc. Brazilian gene bank harbours ex situ germplasm collections of plants, animals and microorganisms (Burle, 2013).

Globally, plant gene banks hold 128,846 accessions of 700 species and 300 genera. Domestication of livestock species began nearly 12,000 years ago as humans have started using them for food and other purposes. More than 6,500 breeds have been classified globally. About 40 mammalian species have been domesticated for food, but the major contribution in livestock production is from 14 species. Almost all major livestock species are found in India. It has been estimated that some 1,500 breeds of the domestic animal species in the world are now at high risk of extinction (Pathak and Gupta, 2013). The diversity of fish is approximately 22,000 (Page and Burr, 1991), with perhaps 35,000 species as the eventual total. Approximately 100 new species of freshwater fish are described each year, compared with perhaps two new bird species.

\section{The Indian Scenario}

It has been reported that 166 crop species belong to the Hindustani Centre (Datta, 2013). The genetic erosion of wild progenitors and relatives of the cultivated crops and domesticated animals and other organisms is alarming globally and India is no exception to this. India is one of the 12 mega biodiversity centers, endowed with wide floristic, fish, animal, marine and microbial diversity. The total geographical area of the country is $3,287,240$ square kilometers. Rodgers and Panwar (1988) attempted to define the bio-geographical regions of India with salient features. They divided India into ten geographically distinct zones viz. Trans-Himalayan, Indian desert, Semi-Arid, Western Ghats, Deccan Peninsula, Gangetic Plains, North East India, Islands and Coasts.

India hosts 45,000 plants and 75,000 animal species. About 30\% of plant species are endemic to India. The Indian subcontinent is an important centre of the origin and diversity of more than 20 major agri-horticultural crops. About 160 domesticated species of economic importance and over 326 species of their wild forms and close relatives are native of this region. India's national gene bank housed at National Bureau of Plant Genetic Resources (NBPGR), New Delhi is a 
multi-crop ex situ repository. It ranked third globally and holds about 0.4 million accessions belonging to 1,586 crop species (Bansal, 2013). Indian plant genetic resources management system is also involved in the harmonization of national and international treaties, and conventions and regulatory mechanism for exchange of germplasm.

India is the seventh largest country in the world with nearly $75 \%$ people engaged in vocations related to various agriculture and animal husbandry. According to the Livestock Census 2007, the country had 530 million livestock population and 649 million poultry population. The genetic erosion of wild and semi-wild relatives of the domesticated crops and animals is alarming due to threats to ecosystems, loss of breeding habitats. So many breeds of the domestic animals are now at high risk of extinction.

\section{Objectives and Time Scale of Genetic Resources Conservation}

The genetic resources conservation is vital, as the basic germplasm materials are required for adapting crops/animals to (a) expanding biotic and abiotic stress, (b) changing consumer preferences, and (c) to feed the ever-increasing world population, as the rise in the population will be around 8.1 billion by 2025 , with most growth in developing countries. Under the current climatic conditions, the main emphasis is on increasing food production for feeding the increasing global population. To increase per capita cereal production, farming everywhere will depend more on information-intensive agricultural management procedures. In recent times, man is mostly depending on modern high yielding varieties of hybrid crops and cross-bred animals for his dietary and other requirements. However, primitive hunter-gatherer and peasant farmers have derived majority of their food from weedy and wild species for their survival and they had started the process of domestication. Nevertheless, the present generation of gene conservationists and breeders has realized the immense potential of wild relatives of cultivated/domesticated life forms for increasing current food production and also for the future use. Table 1 depicting the objective of operators increased over a period of time, for next meal from one day $(<1800 \mathrm{BC})$ to above 100 years $(>1916)$, clearly indicated the expanding preferences.

Table 1. The objective and time scales of concern in genetic resources conservation

\begin{tabular}{|l|l|l|l|}
\hline Period & Operator & Objective & Time scale \\
\hline$<1800 \mathrm{BC}$ & Hunter-gatherer & Next meal & 1 day \\
$<1850 \mathrm{AD}$ & Primitive/traditional peasant farmer & Next crop & 1 year \\
& Plant breeder & Next variety & 10 years + \\
$>1850 \mathrm{AD}$ & Gene conservationist & Genetic base & 100 years + \\
\hline
\end{tabular}

\section{Narrow Genetic Base}

The modern agriculture is facing the problem of narrow genetic base, which lead to yield plateau in recent times. This has been reported in a number of crop plants and animal species. Among the food crops, rice, wheat and maize are the three most important cereal crops feeding the majority of the population in the world. Similar is the case with a few numbers of domesticated animals also. The narrow genetic base is due to unidirectional selection for yield alone, in which the popular cultivars/hybrids contain only a few numbers of genotypes in their parentage. Genetic erosion in the traditional crops/animals species is due to their neglect and also due to 
replacement by high yielding modern varieties. Apart from erosion of traditional germplasm, monoculture leads to the breakdown of resistance to various diseases and pest. Rao et al. (1997) reported the impact of monoculture of crops on environment. Genetic erosion occurs due to the loss of wild progenitors and relatives of the cultivated food crops and domesticated animal populations. So, there is an urgent need to evaluate these forms for identification of diversity and use for broadening the genetic base of the cultivated crops and domesticated animals.

\section{Usefulness of Genetic Diversity}

Genetic diversity existing in the germplasm is very useful in improving the productivity of crop plants and animal species, as they are the reservoir of valuable genes. Usefulness of genetic resources in broadening the narrow genetic base of the cultivated crops, and in enhancing crop productivity and sustainable development, has been reported by several scientists (Rao and Latha, 1996; Rao, 2004). India has wide diversity in millets group of plant populations, and is the largest producer of many kinds of millets viz. sorghum and small millets. These are indispensable to vast array of tribal population and hill agroecosystems as they grown in diverse soils, varying rainfall regimes, different altitudes and areas with varying thermo and photoperiods. Cultivation and utilization of local millet diversity by tribal populations for their survival and nutritional security was well established in different regions- South India (Kimata et al., 2000), Utter Pradesh, Himachal Pradesh (Kimata et al., 1997) and in Maharashtra state, India (Patil and Bhaskar, 2003). In order to achieve both food and nutritional security, we have to focus on under-utilized crops such as millets. Paroda (1996) stated that food/nutritional security involves focusing research on neglected crops such as small millets which can perform in times of environmental stress. The recent scientific literature emphasizes the significance of wild relatives of crop plants in plant breeding programmes for targeted traits with striking case studies or in general reviews (Harlan, 1984; Stalker, 1980). Many researchers have identified for certain specific characters the wide variability, diversity and numerous useful genes from various sources of germplasm. So, these selected genotypes should be incorporated in crop improvement programmes. Modern agriculture in the 21 st century has benefitted immensely by using a few genotypes in developmental programmes. The importance and role of wild germplasm in plant breeding and crop productivity (Frankel and Hawkes, 1975; Hawkes, 1977) and the useful genes from wild plant species for crop improvement programmes were well recognized (Frey, 1976). Utilization of some selected crop plants, showing certain desirable traits are listed in Table 2.

Table 2. Utilization of germplasm in some selected crop plants

\begin{tabular}{|l|l|l|l|}
\hline \multirow{2}{*}{$\begin{array}{l}\text { Character } \\
\text { 1. Plant }\end{array}$} & Crop & Particulars & Source genotype [Gene] \\
\cline { 2 - 4 } & Wheat & Dwarfness & Norin 10 \\
\cline { 2 - 4 } & Rice & Dwarfness & Dee-gee-woo-gen \\
\hline \multirow{2}{*}{$\begin{array}{c}\text { 2. Lodging } \\
\text { resistance }\end{array}$} & Wheat & Dwarfness & MDCH 1 (Madhulika) \\
\hline \multirow{2}{*}{$\begin{array}{c}\text { 3. Disease } \\
\text { resistance }\end{array}$} & Wheat & Resistance & Norin 10 \\
\cline { 3 - 4 } & & Deaf rust & $\begin{array}{l}\text { Aeg-gee-woo-gen } \\
\text { Dove, Centurk, CIM25 Arkan, Blueboy, }\end{array}$ \\
\cline { 3 - 4 } & & Stem rust & Agropyron elongatum [Gene-Lr24, Sr24] \\
\cline { 3 - 4 } & & Kernel bunt & Aegilops squearrosa \\
\cline { 3 - 4 } & Powdery mildew & Aegilops longissima \\
\hline
\end{tabular}

P. Jayaseela Rao, G. Prabhakara Rao, Paresh Chandra Kole 


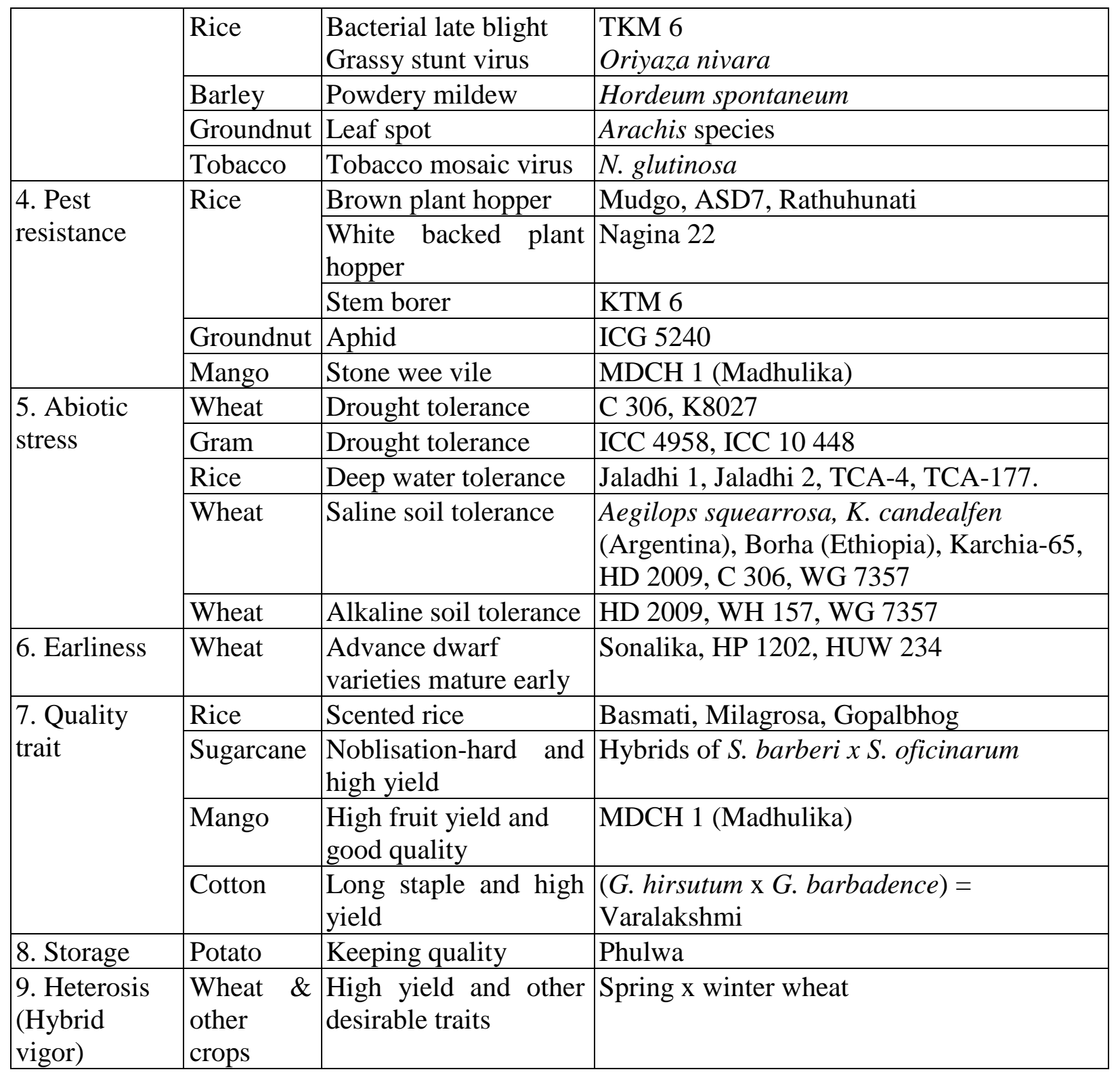

Domestication of livestock species began nearly 12,000 years ago. Man started herding of animals for food, fiber, work, power and other agricultural purposes even before cultivation. Indigenous livestock breeds have sustained human livelihood for centuries (FAO, 2015). Today they represent a treasure trove of diversity and adaptation that remains largely under-exploited (Okeyo et al., 2015). Salient features of $19^{\text {th }}$ livestock census of India indicated that the total livestock population in the country is 529.69 million in 2007 and 512.05 million in 2012 (Anonymous, 2014). The total livestock population has decreased by about $3.33 \%$ over the previous census, which is a case of important concern in the current scenario.

In the case of animal genetic resources, conservation focused on semi-wild, adapted races of exotic species such as cattle, buffaloes, horses, donkeys, pig, goats, sheep, poultry and few collections of native species and microorganisms. In India, livestock productivity levels are generally low as far as milk yield and egg production are concerned. This may be due to poor genetic make-up, scarcity of feeds and unbalanced feeding practices, climate change and emerging diseases. However, this 
can be improved through selective breeding of indigenous animal genetic resources and their adaptability to changing environmental conditions. The domestic animal diversity has economic, scientific, social, cultural and religious values (Pathak and Gupta, 2013).

To mention a few are Vechure cow from Kerala state having stress tolerance, and its milk and ghee have high medicinal values. Ongole cattle from Andhra Pradesh are another example that has high milk productivity. Vechur cattle are the smallest in size breed in the world and among native Indian breeds of Bos indicus cattle. The breed was named after the village Vechoor in Kottayam district of the Kerala state in India. It was listed in the FAO's World Watch List of Domestic Animal Diversity 2000, in the category of 'Critical-Maintained Breeds List' (FAO, 2000). The average height of the Vechur cattle is about $90 \mathrm{~cm}$ and its body weight is about 130 $\mathrm{kg}$. The breed is valued for high amount of milk production compared to the amount of food it required. The Indian subcontinent is the treasure house for Bos indicus cattle breeds that are most suited for livestock production in the tropics, be it for their draught power, milk or meat. On the other hand, Ongole cattle (Bos taurus) are a versatile resource for the tropics and originated from Prakasam and Nellore districts of Andhra Pradesh, India. The Ongole bulls have about $450 \mathrm{~kg}$ weight, $1.6 \mathrm{~m}$ length and $1.5 \mathrm{~m}$ height. Ongoles are bred in the greatest numbers and are the most widely distributed in many countries. By virtue of their adaptability traits and superior productive capacity under harsh tropical conditions, they have been very much sought after and beneficial in tropical cattle production. As per the FAO (2007) report on the state of world's animal genetic resources, India possess very high percentage of animal diversity. India's animal diversity is shown in Table 3.

Table 3. Domestic animal diversity: World vs. India (FAO, 2007).

\begin{tabular}{|l|c|c|c|c|}
\hline \multirow{2}{*}{ Species } & \multicolumn{2}{|c|}{ World (Population \& breeds) } & \multicolumn{2}{|c|}{ India (Population \& breeds) } \\
\cline { 2 - 5 } & $\begin{array}{c}\text { Population } \\
(m)\end{array}$ & Local breeds & $\begin{array}{c}\text { Population } \\
(m)\end{array}$ & $\begin{array}{c}\text { Local breeds listed in India } \\
\text { (Reported by FAO) }\end{array}$ \\
\hline Buffalo & 174 & 137 & 98 & $10(20)$ \\
\hline Cattle & 1355 & 1102 & 185 & $30(60)$ \\
\hline Goat & 808 & 599 & 124 & $20(34)$ \\
\hline Sheep & 1081 & 1229 & 61 & $42(62)$ \\
\hline Pig & 960 & 599 & 14 & $3(8)$ \\
\hline Chicken & 16740 & 1233 & 489 & $18(19)$ \\
\hline $\begin{array}{l}\text { All domestic } \\
\text { species }\end{array}$ & & 7616 & & $140(249)$ \\
\hline
\end{tabular}

\section{Conservation Strategies and Challenges}

Economically important food and other crops are mostly collected and conserved ex situ by various national and international crop research organizations/ institutions. But less economically important plant species are given less importance in collection and conservation processes. Morin (2000) and Anishetty et al. (2016) emphasized the need for proper management of ex situ collections to arrest genetic erosion and also to avoid genetic drift in the population. However, crop wild relatives (CWR), like any other group of wild species, are subjected to increasing threats due to habitat loss, degradation and changing land-use patterns, over-exploitation and climate change, and hence they require immediate collection for their valuable use. The utilization of CWR requires a multidisciplinary linkage at various levels, viz. researchers, 
conservators, policy makers, partners, local communities, especially in a participatory approach. Therefore, the conservation programmes at the national, regional and global levels provide strong recommendations for conservation and use (Heywood et al., 2008). Crop wild relatives of the plant species could be facing the challenge of climate change on a much bigger scale than the habitat destruction and fragmentation in situ (Guarino et al., 2011). In situ or on-farm conservation is important for continuation of evolution of new plant types and natural selection.

Food and Agriculture Organization (FAO), Biodiversity International and other international organizations, and national organizations such as NBPGR and agricultural universities/institutions have played a significant role in formulating certain policies and strategies for genetic resources conservation at global, regional and national levels. Global Consultation on Use and Management of Agrobiodiversity for Sustainable Food Security (GCUMASFA) held in India during 2013 stated that priority areas for work, collection, conservation (in vitro, in situ or on-farm and ex situ), trait specific field evaluation, documentation and sharing mechanism are important for effective use, management and commodity improvement (Anonymous, 2013b). GCUMASFA had also emphasized on employing the modern tools and technologies to better harness the diversity, apart from stressing on studies on ecosystem diversity.

All the collections should be characterized and catalogued morphologically, molecularly for various agronomically important traits, so that the plant breeders can utilize them in genetic improvement programmes. The judicious management, use and conservation of agrobiodiversity are central to any sustainable food production initiative for improving the livelihoods of poor farmers. Therefore, conservation, sustainable use, and fair and equitable sharing of benefits from their use are international concern as flagged by the Convention on Biological Diversity (CBD).

\section{Conclusion}

The erosion of biodiversity, ecosystem and soil fertility is well-recognized world over. Environmental issues like drought, extreme temperatures and atmospheric warming have become increasingly important not only in global context but also in maintaining the long-term productivity of Indian agricultural sector. The Indian subcontinent is an important centre of the origin and diversity of more than 20 major agri-horticultural crops and high livestock diversity. These animal/plant species also provide highly nutritive and quality food products. The present article emphasized the importance of wild plant/animal species collection, as they were endangered, economically important and indigenous to the Indian subcontinent. A diverse germplasm collection is the backbone or bloodline of any crop improvement program. They possess certain specific traits and genes, which are used to meet the currently growing food and nutrition demands. Certain species thrive well in the harsh tropical environmental conditions and possess valuable genes for tolerance to various biotic and abiotic stresses. So conservation of wild plant forms from various diversity sources, and their rapid evaluation, documentation and use is a priority as a strategy to mitigate the climate change. This is to adapt the ever-changing agro-climatic requirements, development of novel crop varieties in response to new biotic and abiotic stresses, and changing consumer preferences. To achieve both food and nutritional security, we have to focus our research on under-utilized crops such as groups of sorghum and small millets which can perform in times of environmental stress. It is evidenced by a large number of disease or insect resistant cultivars or germplasm released and used. Research on crop resistance or tolerance to abiotic stresses (heat, cold, drought, flood, salt, pH, etc.) has not 
received much attention. Therefore, all the available genetic resources should be conserved for the present and future generations for promoting sustainable development in the years to come.

\section{References}

Agrawal, K.K., Shanker, U., Padhyay, A.P. and Gupta, V.K. (2000). Medium range weather forecast for improving farm decision making. Proc. International conference on Managing Natural Resources for Sustainable Agricultural Production in the 21st Century, 14-18, February 2000. New Delhi, India. Vol. 2. pp. 613-614.

Anishetty, N.M., Rao, V.R., Sivaraj, N., Babu, B.S., Sunil, N. and Varaprasad, K.S. (2016). Gene banks: Management of genetic erosion in Ex Situ collections. Indian Journal of Plant Genetic Resources, 29(3): 268- 271.

Anonymous (2013a). Global consultation on use of and management of agrobiodiversity for sustainable food security. In: Mathur, P.N., Sunil Archak and Sonal Dsouza. eds., pp.xiv, Biodiversity International, New Delhi, India, 200p.

Anonymous (2013b). Global consultation on use of and management of agrobiodiversity for sustainable food security. In: Mathur, P.N., Sunil Archak and Sonal Dsouza. eds., pp.11. Biodiversity International, New Delhi, India, 200p.

Anonymous (2014). Salient features of $19^{\text {th }}$ livestock census 2012-All India report. Press Information Bureau, Ministry of Agriculture, Government of India, Department of Animal Husbandry, Diary and Fisheries, Krishi Bhavan, New Delhi, India, 130p.

Bansal, K.C. (2013). Status of conservation and use of genetic resources and implementation of international agreements. Global consultation on use of and management of agrobiodiversity for sustainable food security. In: Mathur, P.N., Sunil Archak. and Sonal Dsouza. eds., Biodiversity International, New Delhi, India, pp. 32-34.

Barbier, E.B. and Lopez, R. (1999). Debt, Poverty and Resource Management in a Rural Smallholder Economy. Paper presented for Royal Economic Society Conference, University of Nottingham, $29^{\text {th }}$ March- $1^{\text {st }}$ April, 1999.

Beech, E., Rivers, M., Oldfield, S. and Smith, P.P. (2017). GlobalTreeSearch - the first complete global database of tree species and country distributions. Journal of Sustainable Forestry, 36(5): 454-489. Doi: 10.1080/10549811.2017.1310049.

Burle, M.L. (2013). Brazil. In: Mathur, P.N., Sunil Archak and Sonal Dsouza. eds., Global consultation on use of and management of agrobiodiversity for sustainable food security, Biodiversity International, New Delhi, India, pp. 76- 80.

Census of India (2011). Office of the Registrar General and Census Commissioner India, Ministry of Home Affairs, Government of India. www:/Censusindia.gov.in/2011common/census information.html.

Dasgupta, P. and Maler, K. (1991). The environment and emerging development issues. In: Proceedings of the World Bank Annual Conference on Development Economics, 1990, pp.101- 131.

Datta, S.K. (2013). Conservation and use of plant genetic resources for food and agriculture: Indian efforts. In: Mathur, P.N., Sunil Archak and Sonal Dsouza, eds., Global consultation on use of and management of agrobiodiversity for sustainable food security, Bioversity International, New Delhi, India, pp. 17- 21.

FAO (2000). World Watch list for Domestic Animal Diversity. In: B.D. Scherf. ed., 3rd ed. Rome: Food and Agriculture Organization (FAO), pp. 726.

FAO (2007). The State of the World's Animal Genetic Resources for Food and Agriculture- in brief. In: Pilling, D. and Barbara Rischkowshy, eds., Rome, Italy: Food and Agriculture Organization, pp. 39. 
FAO (2015). The Second Report on the State of the World's Animal Genetic Resources for Food and Agriculture. In: B.D. Scherf and Pilling, D. eds., FAO commission on Genetic Resources for Food and Agriculture Assessments, Rome, Italy: Food and Agriculture Organization.

Frankel, O.H. and Hawkes, J.G. eds. (1975). Crop Genetic Resources for Today and Tomorrow. Cambridge: Cambridge University Press.

Frey, K.J. (1976). Plant breeding in the seventies: useful genes from wild plant species. Egyptian Journal of Genetics and Cytology, 5: 460-482.

Guarino, L., Rao, V.R., and Goldberg, E. eds. (2011). Collecting plant genetic diversity: Technical Guidelines- 2011 Update. Biodiversity International, Rome, Italy.

Harlan, J.R. (1984). Evaluation of wild relatives of crop plants. In: Crop genetic resources conservation and evaluation. J.H.W. Holden and Williams, J.T. eds., London: George Allen and Unwin, pp. 212-222.

Hawkes, J.G. (1977). The importance of wild germplasm in plant breeding. Euphytica, 26: 615-621.

Heywood, V.H., Kell, S.P. and Maxted, N. (2008). Towards a global strategy for the conservation and use of crop wild relatives. In: Maxted et al. eds., Crop wild relatives conservation and use. Cambridge/New York: CAB International University Press, pp. 657- 666.

Houghton, J.T., Ding, Y., Griggs, D.J., Noquer, M., Van der Linden, P.J. and Xiaosu, D. (2001). Climate Change 2001: The scientific basis. Cambridge, UK: Cambridge University Press, p.944.

IPCC (2014). Climate change 2014: synthesis report. Contribution of Working Groups I, II and III to the Fifth Assessment Report of the Intergovernmental Panel on Climate Change. Core Writing Team. In: R.K. Pachauri and Meyer, L.A. eds., Geneva, Switzerland: IPCC, p.151.

Kimata, M., Ashok, E.G. and Seetharam, A. (2000). Domestication, cultivation and utilization of two small millets Brachiana ramasa and Setaria glauca in South India. Economic Botany, 54: 217- 227.

Kimata, M., Mantur, S.G. and Seetharam, A. (1997). Cultivation and utilization of small millets in hill regions, Uttar Pradesh and Himachal Pradesh, India. Environmental Education Research, Tokyo Gokugei Uni. No. 7: 33- 43.

Kirtman, B., Power, S.B., Adedoyin, J.A., Boer, G.J., Bojariu, R., Camilloni, I., Doblas-Reyes, F.J., Fiore, A.M., Kimoto, M., Meehl, G.A., Prather, M., Sarr, A., Schär, C., Sutton, R., van Oldenborgh, G.J., Vecchi, G. and Wang, H.J. (2013). Near-term climate change: projections and predictability. In: T.F. Stocker, D. Qin, G.K. Plattner, M. Tignor, S.K. Allen, J. Boschung, A. Nauels, Y. Xia, V. Bex and Midgley, P.M. eds., Climate change 2013: the physical science basis. Contribution of Working Group I to the Fifth Assessment Report of the Intergovernmental Panel on Climate Change, Cambridge, UK and New York, USA: Cambridge University Press.

MEA (2005). Millennium ecosystem assessment. Ecosystems and human well-being, Washington, DC. http:// www.maweb.org/documents/ document.356.aspx.pdf (Accessed on May 2012).

Meder, P., Flie Bbach, A. Dubois, D., Gunst, L., Fried, P. and Niggli, U. (2002). Soil fertility and biodiversity in organic farming. Science, 296: 1694 - 1697.

Morin, P.A. (2000). Genetic resources: Opportunities and perspectives for the new century. Conservation Genetics, 1: 271-275.

Moss, A.R., Jouany, J.P. and Newbold, J. (2000). Methane production by Ruminants: Its contribution to global warming. Annals De Zootechnie, 49: 231-253.

Nigam, R, Mishra, H.S., Sharma, A.K. and Kumar, S. (2000). Effect of weather variables on the yield of transplanted rice in mollisols of Tarai region. In: Proc. International conference on Managing Natural Resources for Sustainable Agricultural Production in the 21st 
Century, 14-18, February 2000, New Delhi, India. Vol. 2. pp. 586-588.

Okeyo, A.M., Hanotte, O., Young-Jun, K. and Seoae, C. (2015). African indigenous cattle: Unique genetic resources in a rapidly changing world. Asian-Australasian Journal of Animal Science, 28 (7): 911-921.

Page, L.M., and Burr, B.M. (1991). A Field Guide to Freshwater Fishes. Boston: Houghton Mifflin. Panday, S.C., Singh, R.D. and Mani, V.P. (2000). Probability analysis of rainfall of Hawalbagh (Almora), UP. for crop planning. In: Proc. International conference on Managing Natural Resources for Sustainable Agricultural Production in the 21st Century, 14-18, February 2000, New Delhi, India, Vol. 2. pp. 620-621.

Paroda, R.S. (1996). New Paradigms. The Hindu Survey of Indian Agriculture, pp.17-27.

Pathak, K.M.L. and Gupta, S.C. (2013). Overview of Animal Genetic Resources: Global Perspective. In: Mathur, P.N., Sunil Archak and Sonal Dsouza, eds., Global consultation on use of and management of agrobiodiversity for sustainable food security, Biodiversity International, New Delhi, India, pp. 40- 44.

Patil, B.P. and Ramteke, J.R. (2000). Evaluation of weather parameters as predictors of rice yield in Konkan. In: Proc. International conference on Managing Natural Resources for Sustainable Agricultural Production in the 21st Century, 14-18, February 2000, New Delhi, Vol. 2. pp. 580-582.

Patil, H.M. and Bhaskar, V.V. (2003). Cultivation and utilization of Grain Sorghum Small Millets from Nandurbar District of Maharashtra State. Indian Journal of Plant Genetic Resources, 16(3): 230-236.

Pimm, C.I., Russell, G.J., Gittelman, J.L. and Brooks, T.M. (1995). The future of biodiversity. Science, 269: 347 - 350.

Prakash, C. and Rao, D.H. (1986). Crop production in the rainfed agriculture and distribution of rainfall. Indian Journal of Soil Conservation, 14(2): 23-26.

Rana, R.S. (2015). Interplay of national and international laws on access to biological resources and benefit sharing. Indian Journal of Plant Genetic Resources, 28(2): 165-179.

Rao, G.P, Latha, G.H. and Ram, R. (1997). Monoculture of crop plants and its impact on Environment, Presented at International Seminar on Environment, Energy and Technology, Regional and Global perspectives, 11-15, December 1997, B.H.U., Varanasi, India.

Rao, G.P. (2004). Cereal crop genetic resources for sustainable development. In: Koshy G. and Ommaon V. Ommon, eds., Biodiversity Conservation and Environmental Management. Catholicate College, Pathanamthitta, Kerala, India, pp. 139-150.

Rao, G.P. and Latha, G.H. (1996). Conservation of genetic resources and their usefulness in enhancing crop productivity. Presented at National Seminar on Conservation of Endangered Species and Ecosystems, 5-7, December 1996, B.H.U., Varanasi, India.

Rao, G.V.K. (1992). Impact of dryland farming technology production, income and employment in Ranga Reddy district of Andhra Pradesh, PhD. thesis, A.N.G.R. Agriculture University, Hyderabad, Andhra Pradesh, India.

Rodgers, W.A. and Panwar, H.S. (1988). Planning on wildlife protected area network in India. Vol. 12, WII, Govt. of India, Dehradun, India.

Shively, G.E. (2001). Poverty, consumption risk, and soil conservation. Journal of Development Economics, 65: 267-290.

Stalker, H.T. (1980). Utilization of wild species for crop improvement. Advances in Agronomy, 33: $111-147$.

Thrupp, L.A. (1998). Agricultural biodiversity and food security: Predicaments, policies and practices. World Resources Institute (A Draft Publication), Washington, D.C. 